\title{
Globalization, Redistribution, and the Composition of Public Education Expenditures
}

\author{
Thushyanthan Baskaran \\ Zohal Hessami
}

CESIFO WORKING PAPER NO. 2917

CATEgORY 1: Public FinANCE

JANUARY 2010

\footnotetext{
An electronic version of the paper may be downloaded

- from the SSRN website:

www.SSRN.com

- from the RePEc website:

- from the CESifo website:

www.RePEc.org

www.CESifo-group.org/wp
} 


\title{
Globalization, Redistribution, and the Composition of Public Education Expenditures
}

\begin{abstract}
We analyze whether globalization affects the composition of public expenditures for education by integrating arguments from the Heckscher-Ohlin and the tax competition literature into a common theoretical framework. The model suggests that with increasing global integration, developing countries have strong incentives to shift public education expenditures towards lower education. In industrialized countries, on the other hand, globalization has an ambiguous effect on the composition of public education expenditures. We test and confirm these hypotheses with data on 86 countries over the 1999-2006 period.

JEL-Code: F15, H42, H52.
\end{abstract}

Keywords: globalization, public education, composition of public spending.

Thushyanthan Baskaran

Alfred-Weber Institute for Economics

University of Heidelberg

Bergheimer Strasse 58

69115 Heidelberg

Germany

thushyanthan.baskaran@awi.uni-

heidelberg.de
Zohal Hessami

Department of Economics

University of Konstanz

Box 138

78457 Konstanz

Germany

zohal.hessami@uni-konstanz.de 


\section{Introduction}

Globalization is proceeding at a rapid pace. It is therefore not surprising that several social sciences continue to explore its various implications. Public economists are particularly interested in how global economic integration affects public policies; consequently, a large literature on this question has emerged over the years within the field of Public Economics.

Several authors argue that deepening economic integration may lead to the dissolution of the welfare state and cause social and political instability (Rodrik, 1997; Rudra, 2002). On the one hand, economic integration might increase international tax competition and thus cause lower tax rates on mobile firms (Lee and McKenzie, 1989; Devereux et al., 2008). As a consequence, the tax burden could shift from mobile (capital) to immobile (labor) production factors, and fewer resources might be available for redistributive programs. On the other hand, globalization is often associated with an increase in the cross-border mobility of individuals, which is expected to additionally strain the welfare state. First, because the wealthy and highly qualified can more easily defy high personal tax rates through emigration; second, because generous redistributive transfers might attract the poor and less qualified (Sinn, 2003).

The empirical implication of these arguments is that tax revenues and the amount of redistributive transfers will decline with deepening globalization. But even though these theoretical arguments are persuasive, the available empirical evidence is ambiguous. Shelton (2007) finds that trade openness has had no effect on total government expenditures for a panel of 100 countries over the $1970-2000$ period. ${ }^{1}$ Slemrod (2004) shows that there is a negative correlation between corporate tax rates and openness, even though total tax receipts seem to have been unrelated to openness. Rodrik (1998) and Ram (2009) find that more open countries have higher government expenditures. ${ }^{2}$

This empirical ambiguity is to some extent expected given that globalization may have conflictive effects on fiscal policy. Therefore, the individual effects of globalization could cancel each other out at the level of total government expenditures. In response to this problem, several authors have used less aggregated data, and explored whether globalization has had an effect on the composition of the public budget. Dreher et al. (2008) study in a notable contribution this question with a panel of 108 countries over the 1970-2001 period. However, they find that the composition of public expenditures has not been affected by globalization.

\footnotetext{
${ }^{1}$ Note that the terms globalization and trade openness are used interchangeably in this literature. Globalization is, however, a broader concept than trade openness, and additionally implies, inter alia, a global convergence of cultures and political systems. For a more detailed discussion of the proper meaning of globalization see Bhagwati (2004) and Dreher et al. (2008).

2 Alesina and Wacziarg (1998), however, present evidence that the positive correlation between openness and government size is driven by the fact that smaller countries have a larger public sector and are also more open than larger countries. Benarroch and Pandey (2008) oppose the causal conclusions in Rodrik (1998) by arguing that his models suffer from a reversed causality problem.
} 
Even though Dreher et al. (2008) conduct a thorough analysis, it is possible that their level of aggregation is still too high. They consider relative shifts in, for example, total education and social security expenditures. The drawback of considering such broad spending categories is that the subtler effects of globalization on public budgets might be missed. That is, globalization might have affected the composition of expenditures within broad budget categories, while not changing their relative importance. With respect to public spending on education, for example, globalization could have affected the distribution of education expenditures between lower and higher education, while not affecting the relative importance of education expenditures as a whole vis-a-vis other expenditure categories.

Therefore, we explore in this study whether globalization has an effect on the composition of public education expenditures. More specifically, we analyze how globalization affects the allocation of public education expenditures on primary, secondary, and tertiary programs.

A noteworthy precursor to our study is Ansell (2008). He constructs a model that is based on the insight that industrialized and developing countries have different factor endowments. He derives that globalization will affect the returns to factors of production differently in industrialized and developing countries (see the next section for a more detailed discussion). His model leads to the conclusion that governments in developing countries will attach more importance to primary and less to tertiary education with deepening globalization, while those in industrialized countries will pursue the opposite policy. Even though he also presents some empirical evidence in support of this hypothesis, this particular research question is only one of several in his paper and not fully explored. ${ }^{3}$

We extend Ansell's work in various directions. First, while taking into account that globalization might affect factor prices in industrialized and developing countries differently, we additionally acknowledge the contributions of the literature on international tax competition (surveyed above) in our theoretical model. We argue in the model that globalization increases tax competition and thereby reduces the government's ability to redistribute income through the tax-transfer system. This, in turn, causes governments to rely increasingly on educational policies for redistributive purposes. ${ }^{4}$ Second, we also extend Ansell's empirical analysis by using a more sophisticated measure for the extent of globalization, applying panel data techniques, and controlling for potential endogeneity.

The remainder of this paper is structured as follows. In the next section, we develop a simple theoretical model to analyze the relationship between globalization and the composition of education expenditures. We test the implications of the model with panel data covering 86 countries over the 1999-2006 period in section 3. In section 4, we conclude.

\footnotetext{
${ }^{3}$ Other notable theoretical contributions on the impact of globalization on educational policies are Anderson (2005), Anderson and Konrad (2003), Haupt and Janeba (2009), and Viaene and Zilcha (2002). Apart from Ansell (2008), there is, to our knowledge, no further empirical study on the effect of globalization on the composition of education expenditures.

${ }^{4}$ As discussed in Hanushek et al. (2003), the idea of using educational policies as an alternative means of redistribution is fairly standard.
} 


\section{The model}

\subsection{Framework}

Consider a country that is populated by two groups: individuals who are endowed with a low level of ability $a_{L}$ (group $L$ ), and individuals who are endowed with a high level of ability $a_{H}>a_{L}$ (group $H$ ). These different levels of ability may originate from differences in inborn intelligence, or in the skills and opportunities that an individual "inherits" by being raised within a particular social class.

With respect to the masses of the two population groups, we assume that $M[L]>M[H]$. There are thus more low- than high-ability individuals, which is probably a realistic assumption for most countries. We also normalize $M[H]=1$.

Each individual $i \in I, I=\{L, H\}$ produces an output $y_{I}$ by combining her endowed ability $a_{I}$ with a government-provided productivity-enhancing public good $g_{I}$. We assume that the production function of individual $i$ is of the Cobb-Douglas type; it is given by $y_{i}=a_{I}^{\beta} g_{I}^{1-\beta}, \forall i \in I=\{L, H\}$ with $0<\beta<1$.

In our context, it is appropriate to think of $g_{I}$ as different types of education expenditures. That is, $g_{L}$ could be thought of as spending for lower education. A high value for $g_{L}$ would then signal the government's willingness to increase the income of the low-ability individuals by improving their educational opportunities. Conversely, $g_{H}$ can be thought of as higher education expenditures, which increase the productivity of the high-ability individuals, but are of no direct use to the low-ability individuals.

Even though expenditures for lower education might in reality also directly benefit the highability individuals, any such benefits are likely to be smaller than those they would obtain through higher education expenditures. The assumption that the high-ability individuals do not benefit at all from lower education and the low-ability individuals not at all from higher education is a simple way to capture the fact that different societal groups prefer different compositions of the public budget. Incorporating cross benefits into the model would not qualitatively affect the argument we want to make, but would add several variables to the algebra.

It is apparent that industrialized countries have, inter alia, a relative abundance in highskilled labor, whereas developing countries are relatively abundant in low-skilled labor. This implies that in a world of closed economies, wages for low-skilled labor should be relatively high in industrialized and relatively low in developing countries, while wages for high-skilled labor should be relatively low in industrialized and relatively high in developing countries.

One important effect of globalization is that firms in industrialized countries gain access to the low-skilled labor pool in developing countries, for example by relocating their production plants. This increases the demand for low-skilled workers in developing countries, while decreasing it in industrialized countries. Therefore, the returns to low-skilled labor are likely 
to increase in developing and decrease in industrialized countries with deepening globalization. Conversely, the returns to high-skilled labor will decrease in developing and increase in industrialized countries with globalization.

Consequently, we need to account for this argument, which resembles the factor price equalization theorem from the Heckscher-Ohlin model, in our model. We do this by modeling the price at which the output of individual $i$ can be sold as a function of globalization, which we denote with $A$. The price for the output of an individual $i$ of type $I=\{L, H\}$ is thus given as $p_{I}=p_{I}[A]$. We assume that $p_{H}>p_{L}$ holds both in industrialized and developing countries. What differs in our model between industrialized and developing countries is the sign of $d p_{I} / d A$, the (marginal) effect of globalization on the output prices. It follows from our previous discussion that $d p_{H} / d A>0$ and $d p_{L} / d A<0$ holds for industrialized countries. In developing countries, the signs should be reversed, i. e., $d p_{H} / d A<0$ and $d p_{L} / d A>0$. While this is admittedly a highly simplified application of the insights from the Heckscher-Ohlin model ${ }^{5}$ it captures the important result that international trade leads to a equalization of factor prices (Krugman and Obstfeld, 2005).

The market income of the individual $i$ is then given by

$$
\pi_{i}=p_{I}[A] y_{i}=p_{I}[A] a_{I}^{\beta} g_{I}^{1-\beta}, \forall i \in I=\{L, H\}
$$

Even though taxes can in principle only be collected after production has taken place, it is reasonable to assume that education expenditures are financed through taxation because any productivity enhancing government expenditures have to be paid eventually through tax revenue. ${ }^{6}$

The government's budget constraint is given by

$$
T=M(L) g_{L}+g_{H}+R .
$$

This equation states that a share $T-R$ of total tax revenues $T$ is intended for education expenditures. The remaining portion $R>0$ of the tax revenues is used for redistribution through cash transfers.

Since the low-ability individuals constitute the majority of the population, we assume that the government is exclusively interested in the welfare of this population group. This is a reasonable approximation of reality for democratic countries, and it might also be appropriate for certain types of autocratic states such as populist regimes.

We equate the welfare of an individual with her net-consumption level. The government has, in principle, two decision variables through which it can influence an individual's net-

\footnotetext{
${ }^{5}$ In the standard exposition of the Heckscher-Ohlin model, for example, international trade leads only indirectly to an equalization of factor prices by causing a convergence of prices for traded goods. In our model, however, we do not distinguish between factor and output prices for the sake of brevity. See Krugman and Obstfeld (2005) and Leamer (1995) for a more detailed discussion of the Heckscher-Ohlin model.

${ }^{\circ}$ See Alesina and Rodrik (1994) for a similar approach.
} 
consumption level. It can, first, use education expenditures $g_{I}$, and, second, use direct transfers to redistribute income. We assume that the low-ability individuals are exempt from taxation. The high-ability individuals have to pay a proportional tax $t$ on their market income. Total tax revenues are thus given by

$$
T=t \bar{\pi}_{H}
$$

where $\bar{\pi}_{H}$ denotes the total income of the high-ability individuals as a group (i.e., the tax base), and is given by

$$
\bar{\pi}_{H}=\int_{i \in H} p_{H}[A] a_{i}^{\beta} g_{i}^{1-\beta} d i=p_{H}[A] a_{H}^{\beta} g_{H}^{1-\beta}
$$

Note that the total income of the high-ability individuals is equal to their average income because we have normalized the mass of this group to unity.

Given the above assumptions, the governments's objective function, i. e. the net-consumption of a representative individual belonging to the group of the low-ability individuals, is

$$
\max _{g_{L}, g_{H}, t} V=\pi_{L}+\frac{1}{M[L]} R .
$$

The net-consumption of a low-ability individual is thus given by her own market income $\pi_{L}$, and a per-capita transfer that is equal to the part of the tax revenues, $R$, used for the transfer payments divided by the population mass of the low ability individuals.

\subsection{Mobility and the optimal tax rate}

It follows immediately from the objective function that the government should always choose the highest possible tax rate. However, in reality, the government cannot freely choose the tax rate because it has to take into account that high tax rates reduce the tax base. Emigration of the richly-endowed is one of the most important explanations for an upper limit on redistribution through the tax-transfer system. Therefore, the equilibrium tax rate depends on the extent of international mobility, which we presume in the following to be related to the level of globalization.

We assume that these mobility decisions are made after production has taken place. This implies that a high ability individual, if she chooses to emigrate, takes the income she has already earned to the foreign country, but does not generate any additional income there.

To model these mobility decisions formally, let us presume that a high-ability individual will be indifferent between remaining in the country and emigrating if the following condition holds:

$$
(1-t) \pi_{H}=\left(1-t^{F}-x[A]\right) \pi_{H}
$$


with $t^{F}$ denoting the tax rate if the individual would emigrate (the "foreign" tax rate), and $x[A]$ denoting the costs that have to be incurred in the case of emigration. These costs can be thought of as the monetary representation of the "psychological" stress of losing contact with one's acquaintances, or as the costs of relocating physical assets. They are incurred as a fraction of income because more wealthy individuals usually own more assets and will thus have higher relocation costs. ${ }^{7}$

The costs are modeled as a function of the extent of globalization $A$ with $d x / d A<0$. This assumption captures the fact that one effect of globalization is the lowering of transportation cost, which implies that it becomes easier to visit one's acquaintances in the home country, or to relocate physical assets. Another aspect relates to the spread of English as a modern Lingua Franca and the emergence of a global culture, both of which might reduce the psychological costs of moving to a foreign country.

Solving equation 6 for the equilibrium domestic tax rate gives $t=t^{F}+x[A]$. It is straightforward to show that $d t / d A=d x / d A<0$. That is, the equilibrium tax rate is a (decreasing) function of the extent of globalization, i. e. $t \equiv t^{*}[A]$ (it is also a function of the foreign tax rate, but we suppress this parameter in the following). This is a reasonable result given that globalization is often associated with intensifying tax competition and a decline in the tax burden of the wealthy.

\subsection{The composition of public education expenditures}

Taking into account equations 2 and 3 , and that the eventual tax rate is a function of the level of globalization, the objective function of the government can be rewritten as follows

$$
\max _{g_{L}, g_{H}} V_{t=t^{*}[A]}=\pi_{L}+\frac{1}{M[L]}\left(t^{*}[A] \bar{\pi}_{H}-\left(M[L] g_{L}+g_{H}\right)\right),
$$

with the constraint $t^{*}[A] \bar{\pi}_{H} \geq M[L] g_{L}+g_{H}$.

Differentiating the objective function with respect to the $g_{i}$ and assuming an interior solution $^{8}$, we can show that the $g_{i}$ will be chosen such that

$$
\frac{g_{H}}{g_{L}}=\left(t^{*}[A] \chi[A]\right)^{1 / \beta} \frac{a_{H}}{a_{L}},
$$

with $\chi[A]=p_{H}[A] / p_{L}[A]$.

This equation implies that in equilibrium, the relative amount of resources allocated to higher education will increase with the equilibrium tax rate, the relative value of the output prices, and the relative value of the endowment of the high-ability individuals.

\footnotetext{
${ }^{7}$ We realize that this argument for treating the emigration costs as proportional to income does not equally well apply to the costs due to "psychological" stress, but the proportionality assumption might still be appropriate because high-ability individuals usually have a more "valuable" network of acquaintances in the home country.

${ }^{8}$ This requires, in particular, that the tax rate in equilibrium $t^{*}[A]$ is sufficiently large
} 
When international mobility is prohibitively costly and therefore the extent of globalization low, the tax rate can be set at $t^{*}=1$. The government would then choose an allocation of $g_{H}$ and $g_{L}$ such that the relative share of $g_{H}$ is given by $g_{H} / g_{L}=\chi[A]^{1 / \beta}\left(a_{H} / a_{L}\right)$. Thus, the market income of the high-ability individuals will be relatively large. After redistribution, however, the income distribution would be reversed. In fact, the high-ability individuals will be completely expropriated.

This conclusion is of course unrealistic if it is taken literally. It does, however, mirror a particular pattern of fiscal policy that can be observed in several OECD and many developing countries. In the typical European welfare state, for example, higher education is provided either free of charge or is highly subsidized by the government, even though the majority of the electorate does not directly benefit from these expenditures. At the same time, average and marginal personal income tax rates are relatively high. At first sight, this pattern of fiscal policy makes little sense. According to our model, however, this policy might maximize the consumption possibilities of the income strata that have a low level of ability if tax competition is very low.

As argued by Poutvaara and Kanniainen (2000), such a social consensus to finance higher education publicly may break down once the highly skilled can emigrate more easily. This can also be shown formally in our model by differentiating the first order condition in equation 8 with respect to the level of globalization:

$$
\frac{d}{d A}\left(\frac{g_{H}}{g_{L}}\right)=\Lambda \times\left(\frac{d t^{*}[A]}{d A} \chi[A]+t^{*} \frac{d \chi[A]}{d A}\right),
$$

with $\Lambda=(1 / \beta)\left(t^{*}[A] \chi[A]\right)^{(1-\beta) / \beta}\left(a_{H} / a_{L}\right)$.

Since $\Lambda$ is unambiguously positive, the sign of expression 9 depends upon $\left.\left(d t^{*}[A] / d A\right) \chi[A]\right)+$ $t^{*}(d \chi[A] / d A)$. First, note that we have shown in section 2.2 that $d t^{*} / d A<0$ because globalization intensifies tax competition. The sign of $d \chi[A] / d A$, however, is less obvious. In fact, as argued above, it differs between industrialized and developing countries.

In developing countries, globalization decreases the returns to high-skilled and increases that to low-skilled labor. This implies that $d \chi / d A<0$. Therefore, since both $d t^{*} / d A<0$ and $d \chi / d A<0$, expression 9 will be unambiguously negative in developing countries. In other words, developing countries will shift their educational policies in favor of lower education with deepening globalization.

In industrialized countries, on the other hand, globalization increases the returns to high skilled and reduces that to low-skilled labor. This implies that $d \chi / d A>0$. Therefore, the sign of expression 9 is indeterminate because $d t^{*} / d A<0$. In other words, governments in industrialized countries face conflictive incentives with respect to their educational policies. Whether globalization will induce them to shift their educational programs toward lower or higher education, or not at all, is therefore an empirical question. Given that industrialized 
countries face conflictive incentives, however, one reasonable hypothesis is that globalization will be "neutral" for the composition of education expenditures in this group of countries.

\section{Empirical results}

\subsection{Empirical model and data}

In this section, we test the implications of our theoretical model by estimating several variants of the following general empirical model

$$
y=\alpha_{i}+\omega_{t}+\beta \mathbf{x}+\delta \text { Globalization }+\gamma \text { Globalization } \times \operatorname{Dev}+\epsilon,
$$

where $y$ is a measure for public expenditures for either primary, secondary, or tertiary education, $\alpha_{i}$ country fixed effects, $\omega_{t}$ year fixed effects, $\mathbf{x}$ a vector of control variables (see below), and $\epsilon$ the error term.

In order to test the implications of our theory, we include a measure for globalization and its interaction with a dummy variable that is 1 for "developing" countries ${ }^{9}$. We are interested in the estimate for $\delta$ and $\gamma$, the coefficients attached to the globalization variable and its interaction with the developing country dummy: $\delta$ is the effect of globalization in industrialized countries, whereas $\delta+\gamma$ is its effect in developing countries. Note that we do not have to explicitly include the developing country dummy into this model because of the country fixed effects.

The theoretical model leads two related but distinct empirical predictions. First, the fact that the effect of globalization on the composition of education expenditures is ambiguous in industrialized but unambiguous in developing countries implies that with deepening globalization, developing countries will increase their spending for primary education and reduce their spending for tertiary education at least as much than industrialized countries. This implies that the estimate for $\gamma$ should be weakly positive (i. e., $\gamma \geq 0$ ) for primary and weakly negative (i. e., $\gamma \leq 0$ ) for tertiary education. We label this prediction the Relative Education Hypothesis (REH) because it refers to the relative effect of globalization in developing countries as compared to industrialized countries.

The theoretical model also leads two a second prediction which we label the Absolute Education Hypothesis (AEH). The fact that equation 9 in the theoretical section is unambiguously negative for developing countries suggests that these countries will increase their spending for

\footnotetext{
${ }^{9}$ Any classification of countries as industrialized or developing is of course arbitrary. We take a conservative approach and classify the wealthy "Western" countries cum Japan and South Korea as industrialized. This implies that even OECD countries such as Turkey or Poland are classified as "developing". Therefore, the term developing as used in this paper should not be understood as being synonymous with, for example, the Least Developed Countries (LDC). It should rather be understood as encompassing all countries except the most wealthy. See table 7 in the appendix for a complete list of how we have classified the countries in our sample.
} 
primary and reduce that for tertiary education with deepening globalization. The testable implication of this theoretical result is that the marginal effect of globalization in developing countries, $\delta+\gamma$, should be significantly positive for primary and significantly negative for tertiary education.

Even though the model does not offer a clear prediction for secondary education expenditures, we also consider the impact of globalization on this type of educational program. With regard to this type of education expenditures, we presume that the effect of globalization will be less pronounced than for primary and tertiary education in both industrialized and developing countries.

Our preferred measure for public education expenditures for the three types of educational programs, i.e. the dependent variables in equation 10 , are the expenditures per student, normalized through division by GDP per capita.

We prefer these measures to using "budget shares" (i.e., primary, secondary, and tertiary education expenditures as share of total education expenditures) because we must scale government spending on the three different educational programs by the number of students in these programs. This is done automatically when we use expenditures per student as dependent variable. We conduct, however, further below a sensitivity analysis by using the share of primary, secondary, and tertiary education expenditures in total education expenditures as dependent variable. A concise description of the dependent variables and their sources can be found in table 1 .

With respect to the control variables in equation 10, our measure of globalization is the KOF-index developed by Dreher (2006). The KOF-index is based on three sub-indexes which capture the extent of economic, social, and political globalization. These three sub-indexes are aggregated into one single measure of globalization. We prefer this measure to the simple trade openness variable (exports plus imports divided by GDP) because it takes into account that globalization is a multi-dimensional phenomenon that has broader implications than only to increase international trade. In view of the research questions in this study, an appropriate measure of globalization should, inter alia, additionally capture to what extent English is used as a second language since the ability to communicate in the current Lingua Franca will directly impact international mobility.

We use a diverse set of additional control variables, which are are listed in table 1. Most importantly, we include total education expenditures per student as percent of GDP per capita. This variable has to be controlled for since our aim is to investigate how the relative importance of primary, secondary, tertiary education expenditures (i. e., the composition of education expenditures) has changed with globalization.

We additionally include (i) the size of the population in order to capture economies of scale in the provision of public goods; (ii) total government expenditures as share of GDP in order to control for the economic importance of the public sector; (iii) GDP per capita in order to 
capture how a country's income level is related to the structure of education expenditures; and (iv) a measure of the government's ideology in order to control for systematic partisan biases in education expenditures. The ideology variable is an index that is 1 when the government is left-wing with respect to economic policy, and else $0 .^{10}$

One important variable for which do not explicitly control is the amount private education expenditures. Unfortunately, private education expenditures are difficult to measure for the poorer countries in our sample. However, the propensity of a country to finance education privately can be understood as a relatively time-constant country-specific characteristic. For example, private education expenditures have traditionally been and continue to be more important in Anglo-Saxon than in Continental European countries. We therefore use the country fixed effects to control for the importance of private education expenditures.

Apart from these control variables, we use several additional variables either as controls in the robustness checks, or as instruments, or both. These are, first, the gross enrollment rates for primary, secondary, or tertiary educational programs and, second, the population shares of the age groups relevant for each of the three types of educational programs. In addition, we also consider the amount of development aid paid to certain countries. We explain the rationale for using these variables in the respective sections; they are concisely described in table 1 .

Our unbalanced dataset covers 86 countries, both developing and developed, over the 19992006 period. Summary statistics for all variables used in the subsequent regressions are collected in table 5, a list of the countries that are considered in this study can be found in table 7. Both tables are in the appendix.

Inter alia, the summary statistics in table 5 reveal that the average expenditures per student as percent of GDP per capita are much higher for tertiary $(64.48 \%)$ than for either primary $(16.29 \%)$ or secondary programs $(22.73 \%)$. The same holds with respect to the variability in the three expenditure types as revealed by the standard deviations.

\subsection{Baseline models}

We collect the baseline results in table 2. We estimate a set of four models for each of the different types of education expenditures. All models include the full set of economic and political control variables, and country and year fixed effects (results for these are not reported). For hypothesis tests, we always use robust standard errors. At the bottom of the table (in the row labeled Glob. at Dev=1), we report the marginal effect of globalization in developing countries (i.e., the estimate of $\delta+\gamma$ ) for those models in which we include the interaction between globalization and the developing countries dummy.

\footnotetext{
${ }^{10}$ Note that this ideology variable is derived from the DPI dataset. Whereas this dataset distinguishes between right, center, left, and other governments, we use, for compactness, a 0-1 classification. We code left-wing governments as 1 and all other governments as 0 .
} 
Table 1: Definition AND SOURCE OF VARIABLES

\begin{tabular}{|c|c|c|}
\hline Label & Description & Source \\
\hline \multicolumn{3}{|c|}{ Dependent variables } \\
\hline Primary/Student & $\begin{array}{l}\text { Primary education expenditures per student di- } \\
\text { vided by GDP per capita }\end{array}$ & $\begin{array}{l}\text { UNESCO Institute for } \\
\text { Statistics }\end{array}$ \\
\hline Secondary/Student & $\begin{array}{l}\text { Secondary education expenditures per student di- } \\
\text { vided by GDP per capita }\end{array}$ & $\begin{array}{l}\text { UNESCO Institute for } \\
\text { Statistics }\end{array}$ \\
\hline \multirow[t]{2}{*}{ Tertiary/Student } & $\begin{array}{l}\text { Tertiary education expenditures per student di- } \\
\text { vided by GDP per capita }\end{array}$ & $\begin{array}{l}\text { UNESCO Institute for } \\
\text { Statistics }\end{array}$ \\
\hline & Control variables and instruments & \\
\hline Total/Student & $\begin{array}{l}\text { Total education expenditures per student divided } \\
\text { by GDP per capita }\end{array}$ & $\begin{array}{l}\text { UNESCO Institute for } \\
\text { Statistics }\end{array}$ \\
\hline Globalization & KOF index of globalization & Dreher $(2006)$ \\
\hline Population & Population size & Penn World Table 6.3 \\
\hline Gov. share & Government expenditures as share of GDP & Penn World Table 6.3 \\
\hline GDP p. c. & (real) GDP per capita & Penn World Table 6.3 \\
\hline Ideology & $\begin{array}{l}\text { Index of government ideology with respect to eco- } \\
\text { nomic policy, left-wing }=1 \text {, else } 0\end{array}$ & $\begin{array}{l}\text { Own calculation based } \\
\text { on DPI } 2006 \text { Dataset } \\
\text { (Beck et al. 2001) }\end{array}$ \\
\hline Aid & Development aid /GDP & $\begin{array}{l}\text { World Development In- } \\
\text { dicators }\end{array}$ \\
\hline Primary enrollment & Gross enrollment rate in primary education & $\begin{array}{l}\text { World Development In- } \\
\text { dicators }\end{array}$ \\
\hline Secondary enrollment & Gross enrollment rate in secondary education & $\begin{array}{l}\text { World Development In- } \\
\text { dicators }\end{array}$ \\
\hline Tertiary enrollment & Gross enrollment rate in tertiary education & $\begin{array}{l}\text { World Development In- } \\
\text { dicators }\end{array}$ \\
\hline Primary pop. & $\begin{array}{l}\text { School age population - Primary, as share of total } \\
\text { population }\end{array}$ & $\begin{array}{l}\text { UNESCO Institute for } \\
\text { Statistics }\end{array}$ \\
\hline Secondary pop. & $\begin{array}{l}\text { School age population - Secondary, as share of to- } \\
\text { tal population }\end{array}$ & $\begin{array}{l}\text { UNESCO Institute for } \\
\text { Statistics }\end{array}$ \\
\hline \multirow[t]{2}{*}{ Tertiary pop. } & $\begin{array}{l}\text { School age population - Tertiary, as share of total } \\
\text { population }\end{array}$ & $\begin{array}{l}\text { UNESCO Institute for } \\
\text { Statistics }\end{array}$ \\
\hline & $\begin{array}{c}\text { Additional dependent variables for } \\
\text { sensitivity analysis }\end{array}$ & \\
\hline $\begin{array}{l}\text { Primary/ Total edu. } \\
\text { exp. }\end{array}$ & $\begin{array}{l}\text { Primary education expenditures as share of total } \\
\text { education expenditures (logit transformation) }\end{array}$ & $\begin{array}{l}\text { UNESCO Institute for } \\
\text { Statistics }\end{array}$ \\
\hline $\begin{array}{l}\text { Secondary/Total edu. } \\
\text { exp. }\end{array}$ & $\begin{array}{l}\text { Secondary education expenditures as share of total } \\
\text { education expenditures (logit transformation) }\end{array}$ & $\begin{array}{l}\text { UNESCO Institute for } \\
\text { Statistics }\end{array}$ \\
\hline $\begin{array}{l}\text { Tertiary/Total edu. } \\
\text { exp. }\end{array}$ & $\begin{array}{l}\text { Tertiary education expenditures as share of total } \\
\text { education expenditures (logit transformation) }\end{array}$ & $\begin{array}{l}\text { UNESCO Institute for } \\
\text { Statistics }\end{array}$ \\
\hline
\end{tabular}


These four models successively impose fewer assumptions on the data, thereby making the estimates more robust while simultaneously decreasing their efficiency. If all models produce qualitatively similar results, however, we should be reasonably confident that our conclusions are valid.

The first model for each spending category (entitled FE 1) includes the globalization variable but not its interaction with the developing countries dummy. By not including the interaction effect in this model, we effectively assume that globalization has the same effect in both industrialized and developing countries.

The second model (entitled FE 2) includes the interaction effect and thus takes into account that the marginal effect of globalization might differ between industrialized and developing countries.

The third model (entitled IV), while controlling for all variables that are considered in the second model, takes additionally into account that total education expenditures and the expenditures for primary, secondary, and tertiary education are by construction simultaneously determined. We deal with this endogeneity problem by instrumenting total education expenditures. The IV estimator, while being less efficient than OLS, leads to consistent estimates. We consider this as our preferred model because it is probably the most reasonable compromise between consistency and efficiency.

In the fourth model (entitled IV \& CL), re-estimate of the third model, but conduct the hypothesis tests on the basis of clustered standard errors. This model is therefore robust to arbitrary forms of autocorrelation, but may be particularly inefficient.

We use as instruments for total education expenditures in the third and fourth model (i) the gross enrollment rates and (ii) the population shares of the relevant age groups for the three educational programs (school age population). To minimize the potential for endogeneity problems, we use in each set of regressions for one type of educational program the enrollment and population shares in the other two types. For example, we use as instruments in the models with secondary education expenditures as dependent variable the gross enrollment rate in primary and tertiary education, and the population shares of the age groups relevant for primary and tertiary education. The only exception is the model with primary education expenditures. Here, the Hansen J test for overidentification rejects the null when the gross enrollment rate in tertiary education is used as an instrument. We therefore exclude this variable from our set of instruments in the models with primary education expenditures as dependent variable.

The theoretical rationale for using the different enrollment rates and population shares as instruments is that they are likely to be correlated with total education expenditures. ${ }^{11} \mathrm{As}$

\footnotetext{
${ }^{11}$ Note that the direction of the correlation is not trivial. While a higher overall gross enrollment rate should be positively correlated with higher total education expenditures, this is not necessarily true for the individual gross enrollment rates in the three educational programs. That is, a higher gross enrollment rate in a lower-level educational program implies that the gross enrollment rate in the next higher program tends to be smaller, for example because of repeaters. Since education expenditures per student are on average larger
} 
indicated by the overidentification tests in table 2 , the instruments perform well with respect to this test in all models. The relevance tests, however, indicate that the set of instruments may be weak in the model for secondary education expenditures when clustered standard errors are used.

According to the results in table 2, the estimate for $\delta$ is significantly positive in the model for primary, insignificant in the model for secondary, and significantly negative in the model for tertiary education expenditures when the interaction term is not included (the FE 1 models). These results seems to suggest that globalization is positively associated with primary, unrelated with secondary, and negatively related with tertiary education expenditures.

The remaining models in table 2, however, reveal that these results are driven by the effects of globalization in developing countries. The interaction effect is, as predicted by the $R E H$ hypothesis, always positive for primary and always negative for tertiary education expenditures. In fact, the interaction effect is even significantly different from 0 (this, however, is not necessary to confirm the theory which only predicts that the interaction effects will be weakly positive or negative, respectively). The signs of the interaction effects thus confirm Hypothesis REH.

The second hypothesis, $A E H$, is also confirmed by our results. As the row entitled Glob. at $D e v=1$ shows, the marginal effects of globalization in developing countries, $\delta+\gamma$, is significantly positive in the model for primary and significantly negative in the model for tertiary education expenditures. The effect of globalization in industrialized countries, $\delta$ (when the developing country dummy is 0 ), on the other hand, is always insignificant. In other words, globalization has apparently led to a relative increase in funding for primary and a reduction in funding for tertiary education in developing countries, while displaying a "neutral" effect in the industrialized world.

Note also the the marginal effect of globalization in the model for secondary education expenditures has always, both for industrialized and developing countries, a value that is in between the estimates for the marginal effects in the models for primary and tertiary education expenditures.

With respect to the other control variables, we find that an increase in education expenditures increases spending for all three educational programs since the coefficient for this variable is consistently positive. Apart from total education expenditures, only the population and GDP per capita variable are sometimes significant. When countries become more prosperous, they seem to spend more on primary and secondary education. When countries become more populous, on the other hand, they seem to spend less on primary education.

at higher levels of education, a higher gross enrollment rate at some lower level is therefore not necessarily negatively correlated with total education expenditures. 


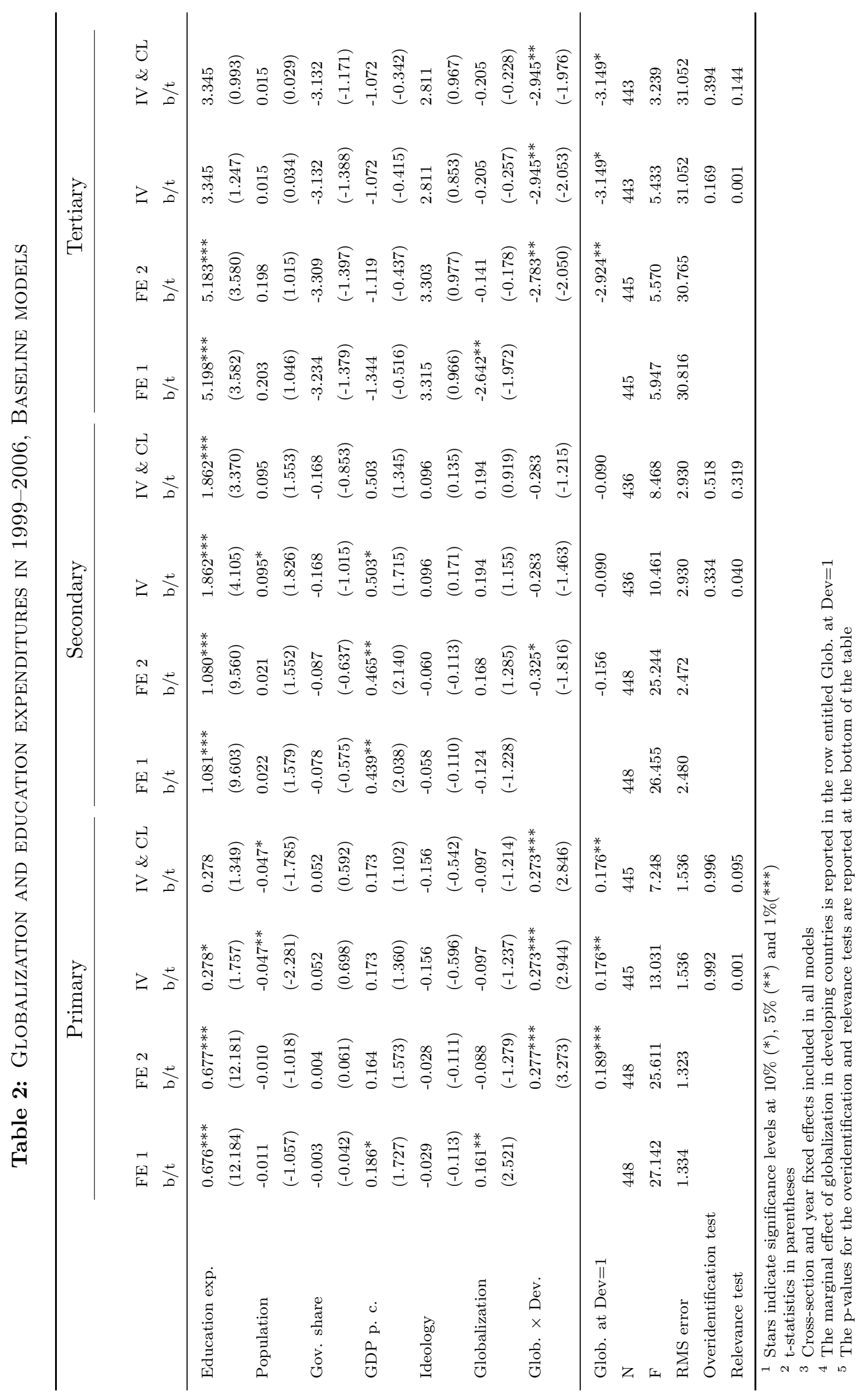




\subsection{Sensitivity analysis}

In this section, we investigate the robustness of our results. In the first set of robustness checks, we divide our sample in industrialized and developing countries and estimate the baseline model separately for each of the two groups of countries. In doing so, we allow not only the coefficient on the globalization variable, but also all other coefficients to vary between industrialized and developing countries.

The results are collected in table 3. For each type of educational program, we estimate two individual models. First, we estimate a pooled OLS model to exploit both the between and within variation (since pooled OLS models take the between variation into account, they can be considered as an additional robustness check). Thereafter, we include country fixed effects and re-estimate the model while only using the within-variation. All models also include year fixed effects, and hypothesis tests are conducted with robust standard errors. Total education expenditures are instrumented with the same instruments as in the baseline models.

First, note that the signs of the coefficient are always the same in the pooled OLS and the fixed effects models. The significance levels, however, tend to be lower in the fixed effects models, but the t-statistics are in general relatively high. Note also that the overidentification test sometimes performs poorly in the pooled OLS models while it always performs well in the fixed effects models. This indicates that the pooled OLS models probably suffer from an omitted variables bias.

Overall, the results from these robustness checks confirm the baseline results. In developing countries, globalization apparently leads to higher primary education expenditures while it seems to have a negative effect on tertiary education expenditures. Conversely, globalization seems to have no effect on education expenditures in industrialized countries as indicated by the insignificant coefficients in the fixed effects models. In other words, the baseline results are confirmed by this set of robustness checks.

In table 4, we report the results from a second set of robustness checks. In these regressions, we study whether the results in the baseline regressions are sensitive to (i) outliers, (ii) to using "budget shares" (primary, secondary, and tertiary education expenditures as share of total education expenditures) instead of spending per student as dependent variable, and (iii) to controlling for development aid. The specification is similar to the baseline models in the sense that we include the interaction of the globalization with that of the developing country dummy variable and all other control variables from the baseline model. 


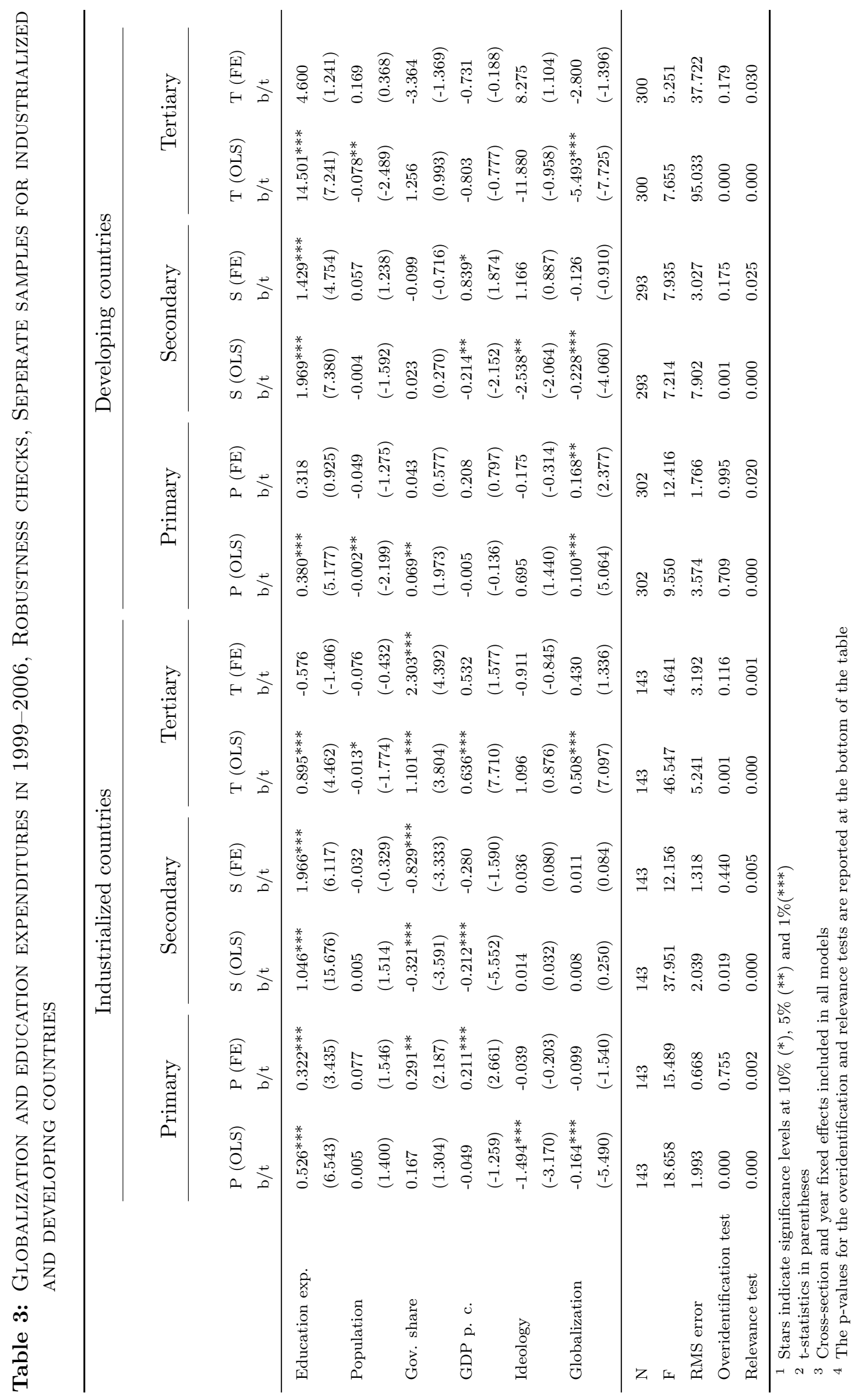


In the models entitled Outliers, we re-estimate our preferred model (IV in table 2) after dropping all observations for which a Grubbs test suggest that they are an outlier. ${ }^{12}$ We use a significance level of $95 \%$ in the models for secondary and tertiary education expenditures. This reduces the number of observations in the model for tertiary education expenditures by a large amount, and in the model for secondary education expenditures somewhat moderately. In the model with primary education expenditures, however, no observations are regared as outliers at a significance level of $95 \%$. We therefore reduce the significance level sucessively for primary education expenditures. But even at a significance level of $50 \%$, only two observations are considered as outliers for this type of expenditures, which suggests that most countries spend similar per capita amounts (scaled by their respective GDP per capita) for primary education.

In the models entitled Budget, we use the alternative measure for public spending on the three types of educational programs. The dependent variables in these models are the budget shares. Since the budget shares are constrained to be between 0 and 100, using them as dependent variables violates the assumptions for OLS to be appropriate. We therefore transform the dependent variables by applying the logistic function before conducting the estimations.

Since the number of students in the three educational programs do not appear at the left-hand side in the Budget models, we have to adapt the right hand-side of equation 10 by explicitly including both the population shares of the relevant age groups and the gross enrollment rates. This is necessary because the "demand" for a particular type of educational spending will increase with the number of student and their enrollment rates.

In the models entitled Aid, we additionally include into the baseline model the amount of development aid divided by GDP as an additional control variable. The rational for including this variable is that donor countries may insist that developing countries use aid for certain types of educational programs. According to Bloom et al. (2006), for example, international donor agencies have generally emphasized lower and deemphasized higher education in developing countries. ${ }^{13}$

As in the baseline models, we need to instrument total education expenditures per student in the Outliers and Aid models. We do that by using the same instruments as in the baseline models. In the Budget models, we do not use instruments and thus report the simple fixed effects estimates. All models include year fixed effects and use robust standard errors for hypothesis tests.

The results for this set of robustness checks are collected in table 4. They largely confirm the baseline results. The interaction effect is generally positive in the primary and negative

\footnotetext{
${ }^{12}$ The Grubbs test has been implemented by Couderc (2007) in Stata.

${ }^{13}$ Note that our original data for the aid variable had missing observations for "wealthy" countries. We replaced these missing observations with 0 to ensure that we can include these countries in the regressions. Note furthermore that several developing countries in our sample had a negative value for the development aid variable in some years. We replaced these values with 0 , too.
} 
Table 4: Globalization and education expenditures in 1999-2006, Robustness Checks, Various SPECIFICATIONS

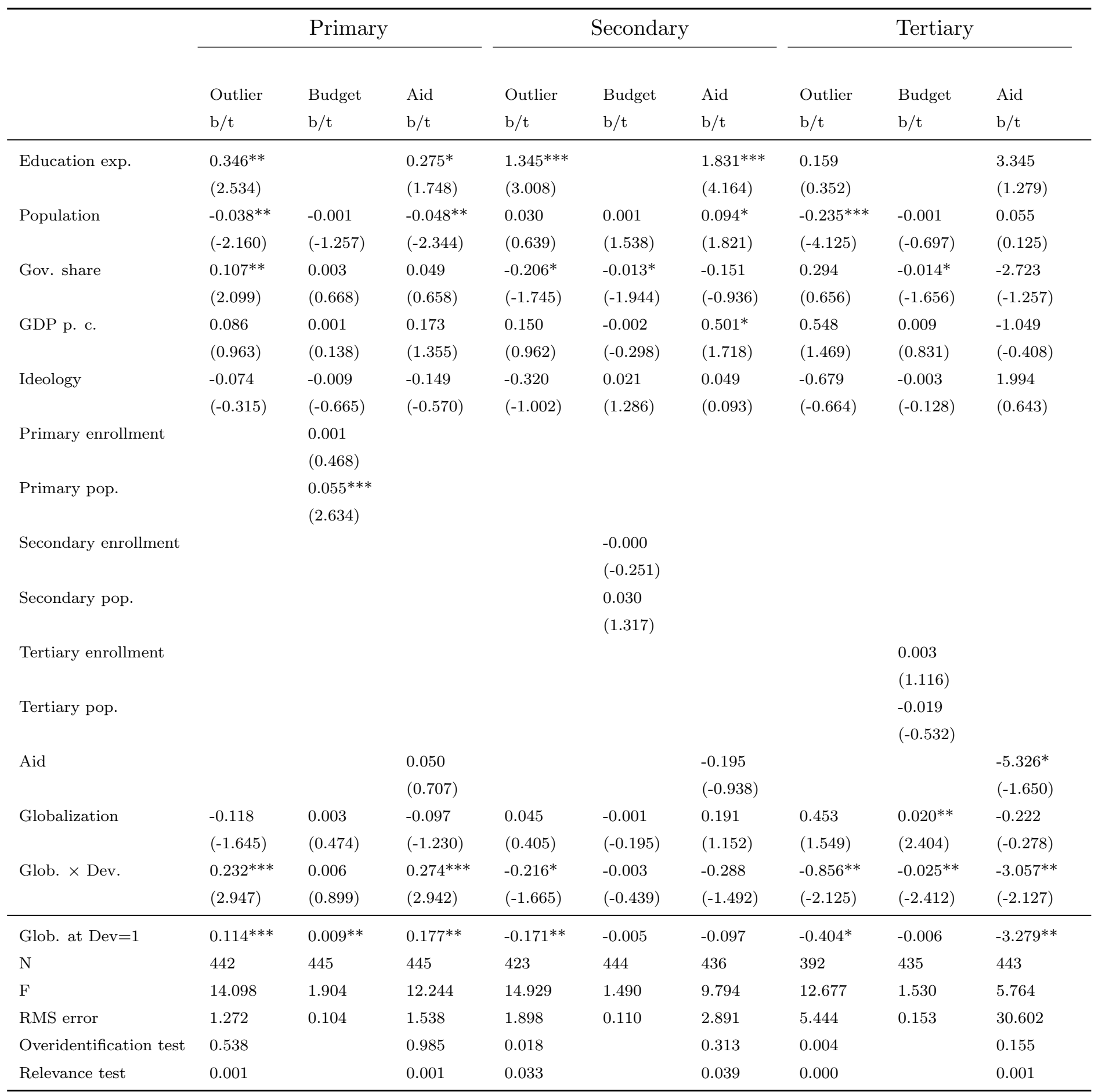

\footnotetext{
1 Stars indicate significance levels at $10 \%(*), 5 \%(* *)$ and $1 \%(* * *)$

2 t-statistics in parentheses

${ }^{3}$ Cross-section and year fixed effects included in all models except models entitled with Average

4 The marginal effect of globalization in developing countries is reported in the row entitled Glob. at Dev=1

5 The p-values for the overidentification and relevance tests are reported at the bottom of the table
} 
in the tertiary education expenditures model. The only exception is the Budget model for primary education expenditures, where the interaction effect is close to 0 (but still positive). On the other hand, the Budget model performs well for tertiary education expenditures. Overall, we consider this as a confirmation of the $R E H$ hypothesis.

The $A E H$ is also largely confirmed. The coefficients in the row entitled with Glob. at $D e v=1$ are always positive for primary education expenditures and always negative for tertiary education expenditures. For tertiary education expenditures, however, the coefficient is insignificant in the Budget model, but still negative. Note also that the overidentification test is rejected in the Outlier model. This is probably due to the large reduction in the sample size.

Overall, both sets of robustness checks largely confirm the baseline results and thus reaffirm the validity of the $R E H$ and $A E H$ hypotheses.

\section{Conclusion}

In this paper, we have analyzed whether globalization is related to the composition of public education expenditures. We first developed a theoretical model which suggested that globalization causes governments in developing countries to adjust public education expenditures away from higher and towards lower education. For industrialized countries, on the other hand, the model suggested an ambiguous effect.

Based on these theoretical results, we formulated two empirical hypotheses. The Relative Education Hypothesis stated that developing countries will increase their spending for primary education and reduce their spending for tertiary education at least as much as industrialized countries. The Absolute Education Hypothesis, on the other hand, stated that developing countries will increase their spending for primary and reduce that for tertiary education with deepening globalization. In the empirical part of our paper, we found robust evidence, i. e., in the baseline models and in sensitivity analyses, for both hypotheses.

Our results thus show that globalization affects the structure of public education expenditures. It apparently shifts the composition of education expenditures towards lower education in developing countries, which might, in the long run, benefit the poor by increasing their productivity. We therefore conclude that governments in developing countries react to globalization by taking steps that mitigate, to some extent, its potentially harmful distributional consequences.

In industrialized countries, on the other hand, globalization seems to have been largely neutral for the composition of public education expenditures. Since the distributional consequences of globalization for low-skilled individuals in industrialized countries are apparently not alleviated by shifts in the composition of public education expenditures, additional measures might be necessary (Sinn, 2005). 
An issue that deserves further attention is whether the pattern between globalization and public education expenditures that we have observed in the empirical investigations is indeed due to the "transmission channels" considered in our theoretical model. While the model provides one explanation for the empirical pattern, there might be competing arguments. A more complete test our our theory should, for example, explicitly show that globalization (i) has reduced the tax burden of the high-skilled while (ii) increasing, with an appropriate time lag, the market income of the low-skilled in developing countries due to the shift in education expenditures.

This, however, is difficult with the available data. With respect to the first point, the problem is to find an appropriate measure of the tax burden of firms and individuals. While this is already a contentious issue for industrialized countries, the situation is even more difficult for developing countries for which the underlying data on taxes is sketchy. With respect to the second point, the unavailability of disaggregated data on the market income of the high- and low-skilled is, especially in developing countries, the main problem. Finding an appropriate strategy to differentiate between different theoretical arguments for the observed empirical pattern is therefore a promising avenue for future research.

\section{Acknowledgments}

We are grateful to the participants of the $3^{\text {rd }}$ CESifo Workshop on Political Economy in Dresden, in particular Heike Auerswald, Henning Bohn, Christian Lessmann, and Thierry A. Verdier, for helpful comments and suggestions.

\section{References}

Alesina, A. and D. Rodrik (1994). Distributive Politics and Economic Growth. Quarterly Journal of Economics 109(2), 465-490.

Alesina, A. and R. Wacziarg (1998). Openness, Country Size and Government. Journal of Public Economics 69(3), 305 - 321.

Anderson, F. and K. A. Konrad (2003). Human Capital Investment and Globalization in Extortionary States. Journal of Public Economics 87(7-8), 1539-1555.

Anderson, T. M. (2005). Migration, Taxation and Educational Incentives. Economics Letters $87(3), 399-405$.

Ansell, B. W. (2008). Traders, Teachers, and Tyrants: Democracy, Globalization, and Public Investment in Education. International Organization 62(2), 289-322. 
Beck, T., G. Clarke, A. Groff, P. Keefer, and P. Walsh (2001). New Tools in Comparative Political Economy: The Database of Political Institutions. World Bank Economic Review 15(1), 165-176.

Benarroch, M. and M. Pandey (2008). Trade Openness and Government Size. Economics Letters $101(3), 157-59$.

Bhagwati, J. (2004). In Defense of Globalization. New York: Oxford University Press.

Bloom, D., D. Canning, and K. Chan (2006). Higher Education and Economic Development in Africa. Harvard University Working Paper.

Couderc, N. (2007). GRUBBS: Stata Module to Perform Grubbs' Test for Outliers. Statistical Software Components, Boston College Department of Economics.

Devereux, M. P., B. Lockwood, and M. Redoano (2008). Do Countries Compete Over Corporate Tax Rates. Journal of Public Economics 92(5-6), 1210-1235.

Dreher, A. (2006). Does Globalization Affect Growth? Evidence From a New Index of Globalization. Applied Economics 38(10), 1091-1110.

Dreher, A., N. Gaston, and P. Martens (2008). Measuring Globalisation. New York: Springer.

Dreher, A., J.-E. Sturm, and H. Ursprung (2008). The Impact of Globalization on the Composition of Government Expenditures: Evidence from Panel Data. Public Choice 134(3), 263-292.

Hanushek, E. A., C. K. Y. Leung, and K. Yilmaz (2003). Redistribution Through Education and Other Transfer Mechanisms. Journal of Monetary Economics 50(8), 1719-1750.

Haupt, A. and E. Janeba (2009). Education, Redistribution, and the Threat of Brain Drain. International Tax and Public Finance 16(1), 1-24.

Krugman, P. R. and M. Obstfeld (2005). International Economics: Theory and Policy. New York: Prentice Hall.

Leamer, E. E. (1995). The Hecksher-Ohlin Model in Theory and Practice. New Jersey: Princeton University Press.

Lee, D. R. and R. McKenzie (1989). The International Political Economy of Declining Tax Rates. National Tax Journal 42(1), 79-83.

Poutvaara, P. and V. Kanniainen (2000). Why Invest in Your Neighbor? Social Contract on Educational Investment. International Tax and Public Finance 7(4), 547-562. 
Ram, R. (2009). Openness, Country Size, and Government Size: Additional Evidence from a Large Cross-Country Panel. Journal of Public Economics 93(1-2), 213-218.

Rodrik, D. (1997). Has Globalization Gone Too Far? Washington: Institute For International Economics.

Rodrik, D. (1998). Why do More Open Economies Have Bigger Governments? Journal of Political Economy 106(5), 997-1032.

Rudra, N. (2002). Globalization and the Decline of the Welfare State in Less-developed Countries. International Organization 56(2), 411-445.

Shelton, C. (2007). The Size and Composition of Government Expenditure. Journal of Public Economics 91(11-12), 2230-2260.

Sinn, H.-W. (2003). The New Systems Competition. Yrjö Jahnsson Lectures. Oxford: Basil Blackwell.

Sinn, H.-W. (2005). Migration and Social Replacement Incomes. How to Protect Low-income Workers in the Industrialized Countries against the Forces of Globalization and Market Integration. International Tax and Public Finance 12(4), 375-393.

Slemrod, J. (2004). Are Corporate Tax Rates, or Countries, Converging? Journal of Public Economics 88(6), 1169-1186.

Viaene, J.-M. and I. Zilcha (2002). Public Education Under Capital Mobility. Journal of Economic Dynamics and Control 26(12), 2005-2036. 


\section{Appendix}

Table 5: Summary statistics

\begin{tabular}{|c|c|c|c|c|c|c|}
\hline Variable & Variance & Mean & SD & Min & Max & Obs. \\
\hline \multirow[t]{3}{*}{ Education exp. } & overall & 20.87 & 6.68 & 7.20 & 47.60 & 448 \\
\hline & between & & 6.77 & 8.08 & 41.07 & \\
\hline & within & & 1.86 & 13.07 & 27.47 & \\
\hline \multirow[t]{3}{*}{ Population } & overall & 36.43 & 107.56 & 0.19 & 1093.56 & 448 \\
\hline & between & & 119.11 & 0.19 & 1057.67 & \\
\hline & within & & 3.38 & -17.11 & 72.32 & \\
\hline \multirow[t]{3}{*}{ Gov. share } & overall & 17.02 & 6.52 & 7.32 & 53.43 & 448 \\
\hline & between & & 7.38 & 8.07 & 42.62 & \\
\hline & within & & 1.37 & 8.42 & 27.83 & \\
\hline \multirow[t]{3}{*}{ GDP p. c. } & overall & 16.38 & 11.64 & 0.65 & 45.69 & 448 \\
\hline & between & & 11.58 & 0.67 & 42.79 & \\
\hline & within & & 1.24 & 10.60 & 21.86 & \\
\hline \multirow[t]{3}{*}{ Ideology } & overall & 0.31 & 0.46 & 0 & 1 & 448 \\
\hline & between & & 0.41 & 0 & 1 & \\
\hline & within & & 0.22 & -0.54 & 1.17 & \\
\hline \multirow[t]{3}{*}{ Aid } & overall & 2.10 & 5.50 & 0.00 & 54.03 & 428 \\
\hline & between & & 7.05 & 0.00 & 46.01 & \\
\hline & within & & 0.91 & -5.70 & 10.12 & \\
\hline \multirow[t]{3}{*}{ Globalization } & overall & 68.44 & 14.11 & 28.43 & 92.19 & 448 \\
\hline & between & & 14.90 & 30.45 & 91.68 & \\
\hline & within & & 2.07 & 59.56 & 76.11 & \\
\hline \multirow[t]{3}{*}{ Primary/Student } & overall & 16.29 & 5.50 & 5.20 & 37.30 & 448 \\
\hline & between & & 5.42 & 6.20 & 32.95 & \\
\hline & within & & 1.86 & 6.74 & 30.78 & \\
\hline \multirow{3}{*}{$\begin{array}{l}\text { Pop. share } \\
\text { primary }\end{array}$} & overall & 9.95 & 4.03 & 3.51 & 19.40 & 448 \\
\hline & between & & 4.22 & 3.85 & 19.17 & \\
\hline & within & & 0.42 & 7.87 & 11.50 & \\
\hline \multirow{3}{*}{$\begin{array}{l}\text { Gross enroll. } \\
\text { primary }\end{array}$} & overall & 104.13 & 10.64 & 56.19 & 154.44 & 446 \\
\hline & between & & 12.54 & 57.98 & 145.70 & \\
\hline & within & & 3.36 & 87.91 & 120.36 & \\
\hline \multirow[t]{3}{*}{ Secondary/Student } & overall & 22.73 & 10.96 & 6.90 & 100.20 & 448 \\
\hline & between & & 12.53 & 8.83 & 82.87 & \\
\hline & within & & 3.03 & 8.63 & 40.07 & \\
\hline
\end{tabular}




\begin{tabular}{|c|c|c|c|c|c|c|}
\hline \multirow{3}{*}{$\begin{array}{l}\text { Pop. share } \\
\text { secondary }\end{array}$} & overall & 10.93 & 3.10 & 5.85 & 20.00 & 448 \\
\hline & between & & 3.22 & 6.37 & 19.65 & \\
\hline & within & & 0.32 & 9.57 & 11.90 & \\
\hline \multirow{3}{*}{$\begin{array}{l}\text { Gross enroll. } \\
\text { secondary }\end{array}$} & overall & 87.94 & 28.32 & 10.32 & 161.66 & 445 \\
\hline & between & & 31.75 & 11.89 & 153.72 & \\
\hline & within & & 5.12 & 58.53 & 113.73 & \\
\hline \multirow[t]{3}{*}{ Tertiary/Student } & overall & 64.48 & 106.22 & 5.10 & 1141.50 & 445 \\
\hline & between & & 130.76 & 8.20 & 845.47 & \\
\hline & within & & 30.41 & -98.82 & 360.51 & \\
\hline \multirow{3}{*}{$\begin{array}{l}\text { Pop. share } \\
\text { tertiary }\end{array}$} & overall & 8.25 & 1.64 & 5.21 & 13.73 & 445 \\
\hline & between & & 1.55 & 5.77 & 13.11 & \\
\hline & within & & 0.33 & 6.82 & 9.67 & \\
\hline \multirow{3}{*}{$\begin{array}{l}\text { Gross enroll. } \\
\text { tertiary }\end{array}$} & overall & 40.02 & 24.83 & 0.89 & 93.22 & 436 \\
\hline & between & & 25.13 & 1.07 & 87.00 & \\
\hline & within & & 4.90 & 20.17 & 63.73 & \\
\hline \multirow{3}{*}{$\begin{array}{l}\text { Primary/Total } \\
\text { edu. exp. }\end{array}$} & overall & 31.93 & 11.40 & 7.80 & 71.20 & 445 \\
\hline & between & & 12.38 & 8.83 & 69.00 & \\
\hline & within & & 2.11 & 20.19 & 44.90 & \\
\hline \multirow{3}{*}{$\begin{array}{l}\text { Secondary/Total } \\
\text { edu. exp. }\end{array}$} & overall & 37.67 & 8.31 & 10.30 & 57.70 & 444 \\
\hline & between & & 8.89 & 10.90 & 54.83 & \\
\hline & within & & 2.27 & 26.74 & 46.57 & \\
\hline \multirow{3}{*}{$\begin{array}{l}\text { Tertiary/Total } \\
\text { edu. exp. }\end{array}$} & overall & 20.27 & 6.84 & 4.20 & 40.30 & \\
\hline & between & & 6.94 & 5.20 & 36.63 & \\
\hline & within & & 2.08 & 11.88 & 33.03 & \\
\hline
\end{tabular}

Table 6: Cross-Correlation table

\begin{tabular}{lcccccc}
\hline \multicolumn{1}{c}{ Variables } & $\begin{array}{c}\text { Primary/ } \\
\text { Student }\end{array}$ & $\begin{array}{c}\text { Secondary/ } \\
\text { Student }\end{array}$ & $\begin{array}{c}\text { Tertiary/ } \\
\text { Student }\end{array}$ & $\begin{array}{c}\text { Primary/ } \\
\text { Total } \\
\text { edu. exp. }\end{array}$ & $\begin{array}{c}\text { Secondary/ } \\
\text { Total } \\
\text { edu. exp. }\end{array}$ & $\begin{array}{c}\text { Tertiary/ } \\
\text { Total } \\
\text { edu. exp. }\end{array}$ \\
\hline Primary/Student & 1.000 & & & & & \\
Secondary/Student & 0.422 & 1.000 & & & & \\
Tertiary/Student & 0.009 & 0.509 & 1.000 & & & \\
Primary/Total & -0.054 & -0.004 & 0.314 & 1.000 & & \\
Secondary/Total edu. exp. & 0.071 & 0.201 & -0.316 & -0.671 & 1.000 & 1.000 \\
Tertiary/Total edu. exp. & 0.102 & 0.052 & 0.132 & -0.387 & -0.109 & 1 \\
\hline
\end{tabular}


Table 7: InCLuded COUnTRIes

\begin{tabular}{lll}
\hline Argentina (D) & Hungary (D) & Oman (D) \\
Australia & Iceland & Panama (D) \\
Austria & India (D) & Paraguay (D) \\
Azerbaijan (D) & Iran (D) & Peru (D) \\
Barbados (D) & Ireland & Philippines (D) \\
Belgium & Israel (D) & Poland (D) \\
Belize (D) & Italy & Portugal \\
Benin (D) & Jamaica (D) & Romania (D) \\
Bolivia (D) & Japan & Rwanda (D) \\
Brazil (D) & Kenya (D) & Samoa (D) \\
Bulgaria (D) & Korea & Senegal (D) \\
Burkina Faso (D) & Kuwait (D) & Slovak Republic (D) \\
Burundi (D) & Latvia (D) & Slovenia (D) \\
Cameroon (D) & Lesotho (D) & South Africa (D) \\
Cape Verde (D) & Lithuania (D) & Spain \\
Chad (D) & Madagascar (D) & Swaziland (D) \\
Chile (D) & Malaysia (D) & Sweden \\
Colombia (D) & Mali (D) & Tajikistan (D) \\
Costa Rica (D) & Malta (D) & Thailand (D) \\
Cote d‘Ivoire (D) & Mauritania (D) & Trinidad \&Tobago (D) \\
Cyprus (D) & Mauritius (D) & Tunisia (D) \\
Czech Republic (D) & Mexico (D) & Turkey (D) \\
Denmark & Mongolia (D) & Ukraine (D) \\
El Salvador (D) & Morocco (D) & United Arab Emirates (D) \\
Estonia (D) & Namibia (D) & United Kingdom \\
Finland & Nepal (D) & United States \\
France & Netherlands & Uruguay (D) \\
Greece & New Zealand & Vanuatu (D) \\
Guyana (D) & Norway & \\
\hline 1 Countries classified by us as "developing" are indicated with a "D" in parentheses \\
2 See footnote9for an explanation of the criteria according to which a country is classified \\
as developing or industrialized & \\
& &
\end{tabular}




\section{CESifo Working Paper Series}

for full list see www.cesifo-group.org/wp

(address: Poschingerstr. 5, 81679 Munich, Germany, office@cesifo.de)

2857 M. Hashem Pesaran and Paolo Zaffaroni, Optimality and Diversifiability of Mean Variance and Arbitrage Pricing Portfolios, November 2009

2858 Davide Sala, Philipp J.H. Schröder and Erdal Yalcin, Market Access through Bound Tariffs, November 2009

2859 Ben J. Heijdra and Pim Heijnen, Environmental Policy and the Macroeconomy under Shallow-Lake Dynamics, November 2009

2860 Enrico Spolaore, National Borders, Conflict and Peace, November 2009

2861 Nina Czernich, Oliver Falck, Tobias Kretschmer and Ludger Woessmann, Broadband Infrastructure and Economic Growth, December 2009

2862 Evžen Kočenda and Martin Vojtek, Default Predictors and Credit Scoring Models for Retail Banking, December 2009

2863 Christian Gollier and Martin L. Weitzman, How Should the Distant Future be Discounted when Discount Rates are Uncertain?, December 2009

2864 Tiberiu Dragu and Mattias Polborn, Terrorism Prevention and Electoral Accountability, December 2009

2865 Torfinn Harding and Beata Smarzynska Javorcik, A Touch of Sophistication: FDI and Unit Values of Exports, December 2009

2866 Matthias Dischinger and Nadine Riedel, There's no Place like Home: The Profitability Gap between Headquarters and their Foreign Subsidiaries, December 2009

2867 Andreas Haufler and Frank Stähler, Tax Competition in a Simple Model with Heterogeneous Firms: How Larger Markets Reduce Profit Taxes, December 2009

2868 Steinar Holden, Do Choices Affect Preferences? Some Doubts and New Evidence, December 2009

2869 Alberto Asquer, On the many Ways Europeanization Matters: The Implementation of the Water Reform in Italy (1994-2006), December 2009

2870 Choudhry Tanveer Shehzad and Jakob De Haan, Financial Reform and Banking Crises, December 2009

2871 Annette Alstadsæter and Hans Henrik Sievertsen, The Consumption Value of Higher Education, December 2009 
2872 Chris van Klaveren, Bernard van Praag and Henriette Maassen van den Brink, Collective Labor Supply of Native Dutch and Immigrant Households in the Netherlands, December 2009

2873 Burkhard Heer and Alfred Maußner, Computation of Business-Cycle Models with the Generalized Schur Method, December 2009

2874 Carlo Carraro, Enrica De Cian and Massimo Tavoni, Human Capital Formation and Global Warming Mitigation: Evidence from an Integrated Assessment Model, December 2009

2875 André Grimaud, Gilles Lafforgue and Bertrand Magné, Climate Change Mitigation Options and Directed Technical Change: A Decentralized Equilibrium Analysis, December 2009

2876 Angel de la Fuente, A Mixed Splicing Procedure for Economic Time Series, December 2009

2877 Martin Schlotter, Guido Schwerdt and Ludger Woessmann, Econometric Methods for Causal Evaluation of Education Policies and Practices: A Non-Technical Guide, December 2009

2878 Mathias Dolls, Clemens Fuest and Andreas Peichl, Automatic Stabilizers and Economic Crisis: US vs. Europe, December 2009

2879 Tom Karkinsky and Nadine Riedel, Corporate Taxation and the Choice of Patent Location within Multinational Firms, December 2009

2880 Kai A. Konrad, Florian Morath and Wieland Müller, Taxation and Market Power, December 2009

2881 Marko Koethenbuerger and Michael Stimmelmayr, Corporate Taxation and Corporate Governance, December 2009

2882 Gebhard Kirchgässner, The Lost Popularity Function: Are Unemployment and Inflation no longer Relevant for the Behaviour of Germany Voters?, December 2009

2883 Marianna Belloc and Ugo Pagano, Politics-Business Interaction Paths, December 2009

2884 Wolfgang Buchholz, Richard Cornes and Dirk Rübbelke, Existence and Warr Neutrality for Matching Equilibria in a Public Good Economy: An Aggregative Game Approach, December 2009

2885 Charles A.E. Goodhart, Carolina Osorio and Dimitrios P. Tsomocos, Analysis of Monetary Policy and Financial Stability: A New Paradigm, December 2009

2886 Thomas Aronsson and Erkki Koskela, Outsourcing, Public Input Provision and Policy Cooperation, December 2009 
2887 Andreas Ortmann, "The Way in which an Experiment is Conducted is Unbelievably Important": On the Experimentation Practices of Economists and Psychologists, December 2009

2888 Andreas Irmen, Population Aging and the Direction of Technical Change, December 2009

2889 Wolf-Heimo Grieben and Fuat Şener, Labor Unions, Globalization, and Mercantilism, December 2009

2890 Conny Wunsch, Optimal Use of Labor Market Policies: The Role of Job Search Assistance, December 2009

2891 Claudia Buch, Cathérine Tahmee Koch and Michael Kötter, Margins of International Banking: Is there a Productivity Pecking Order in Banking, too?, December 2009

2892 Shafik Hebous and Alfons J. Weichenrieder, Debt Financing and Sharp Currency Depreciations: Wholly vs. Partially Owned Multinational Affiliates, December 2009

2893 Johannes Binswanger and Daniel Schunk, What is an Adequate Standard of Living during Retirement?, December 2009

2894 Armin Falk and James J. Heckman, Lab Experiments are a Major Source of Knowledge in the Social Sciences, December 2009

2895 Hartmut Egger and Daniel Etzel, The Impact of Trade on Employment, Welfare, and Income Distribution in Unionized General Oligopolistic Equilibrium, December 2009

2896 Julian Rauchdobler, Rupert Sausgruber and Jean-Robert Tyran, Voting on Thresholds for Public Goods: Experimental Evidence, December 2009

2897 Michael McBride and Stergios Skaperdas, Conflict, Settlement, and the Shadow of the Future, December 2009

2898 Ben J. Heijdra and Laurie S. M. Reijnders, Economic Growth and Longevity Risk with Adverse Selection, December 2009

2899 Johannes Becker, Taxation of Foreign Profits with Heterogeneous Multinational Firms, December 2009

2900 Douglas Gale and Piero Gottardi, Illiquidity and Under-Valuation of Firms, December 2009

2901 Donatella Gatti, Christophe Rault and Anne-Gaël Vaubourg, Unemployment and Finance: How do Financial and Labour Market Factors Interact?, December 2009

2902 Arno Riedl, Behavioral and Experimental Economics Can Inform Public Policy: Some Thoughts, December 2009 
2903 Wilhelm K. Kohler and Marcel Smolka, Global Sourcing Decisions and Firm Productivity: Evidence from Spain, December 2009

2904 Marcel Gérard and Fernando M. M. Ruiz, Corporate Taxation and the Impact of Governance, Political and Economic Factors, December 2009

2905 Mikael Priks, The Effect of Surveillance Cameras on Crime: Evidence from the Stockholm Subway, December 2009

2906 Xavier Vives, Asset Auctions, Information, and Liquidity, January 2010

2907 Edwin van der Werf, Unilateral Climate Policy, Asymmetric Backstop Adoption, and Carbon Leakage in a Two-Region Hotelling Model, January 2010

2908 Margarita Katsimi and Vassilis Sarantides, Do Elections Affect the Composition of Fiscal Policy?, January 2010

2909 Rolf Golombek, Mads Greaker and Michael Hoel, Climate Policy without Commitment, January 2010

2910 Sascha O. Becker and Ludger Woessmann, The Effect of Protestantism on Education before the Industrialization: Evidence from 1816 Prussia, January 2010

2911 Michael Berlemann, Marco Oestmann and Marcel Thum, Demographic Change and Bank Profitability. Empirical Evidence from German Savings Banks, January 2010

2912 Øystein Foros, Hans Jarle Kind and Greg Shaffer, Mergers and Partial Ownership, January 2010

2913 Sean Holly, M. Hashem Pesaran and Takashi Yamagata, Spatial and Temporal Diffusion of House Prices in the UK, January 2010

2914 Christian Keuschnigg and Evelyn Ribi, Profit Taxation and Finance Constraints, January 2010

2915 Hendrik Vrijburg and Ruud A. de Mooij, Enhanced Cooperation in an Asymmetric Model of Tax Competition, January 2010

2916 Volker Meier and Martin Werding, Ageing and the Welfare State: Securing Sustainability, January 2010

2917 Thushyanthan Baskaran and Zohal Hessami, Globalization, Redistribution, and the Composition of Public Education Expenditures, January 2010 